\title{
Konstruksi Aktivitas Berkombur Bermuatan Nilai Kekerabatan Budaya Melayu sebagai Upaya Modifikasi Kecakapan Interpersonal Siswa
}

\author{
Muhammad Khuzairi Batubara $^{1}$, Adi Atmoko ${ }^{1}$, Andi Mappiare-AT ${ }^{1}$ \\ ${ }^{1}$ Bimbingan Konseling-Universitas Negeri Malang
}

\begin{tabular}{l}
\hline \hline INFO ARTIKEL \\
\hline Riwayat Artikel: \\
Diterima: 02-07-2019 \\
Disetujui: $24-10-2019$ \\
\hline
\end{tabular}

Kata kunci:

berkombur activities; kisnship value; interpersonal skills; aktivitas berkombur; nilai kekerabatan;

kecakapan interpersonal

\author{
Alamat Korespondensi: \\ Muhammad Khuzairi Batubara \\ Bimbingan dan Konseling \\ Universitas Negeri Malang \\ Jalan Semarang 5 Malang \\ E-mail: muhammadkhuzairi8@gmail.com
}

\begin{abstract}
Berkombur is an activity of communicating both verbally and nonverbally by a group. The purpose of this activity is as a means of socializing, entertainment, increasing friendship, a problem solving and most importantly by inserting humor at each discussion of the theme so that the feeling of saturation and fatigue all day long works away with a happy laugh. This activity is a characteristic of Batubara Melayu culture. The purpose of this study is to describe kinship values in combat activities and obtain construction procedures as an effort to modify students' interpersonal skills. The method used is a descriptive qualitative approach with a type of dialogue research. The research subject is a student who is an expert in the activity. Coupled with BK teachers, the community, and Malayu humanist. The instrument of data collection uses participant observation and interviews. Data analysis by reducing data, presenting data and drawing conclusions. The results of the study show that there are eight values in the activity which are grouped into kinship values, and obtaining construction implementation in conducting berkombur activities as an effort to modify interpersonal skills.
\end{abstract}

ABSTRAK

\begin{abstract}
Abstrak: Berkombur adalah suatu kegiatan berkomunikasi baik secara verbal maupun nonverbal yang dilakukan suatu kelompok. Tujuan dari aktivitas ini sebagai sarana bersosial, hiburan, meningkatkan silaturahmi, penyelesaian suatu masalah dan menyisipkan humor pada setiap pembahasan tema sehingga rasa jenuh dan letih seharian bekerja hilang dengan tertawa gembira. Aktivitas ini menjadi ciri khas budaya Melayu Batubara. Tujuan dari kajian ini adalah mendeskripsikan nilai-nilai kekerabatan dalam aktivitas berkombur dan memperoleh konstruksi prosedur sebagai upaya modifikasi kecakapan interpersonal siswa. Metode yang digunakan adalah pendekatan kualitatif deskriptif dengan tipe riset dialog. Subjek penelitian yaitu seorang siswa yang ahli dengan kegiatan tersebut. Ditambah dengan guru BK, Masyarakat, serta budayawan melayu. Instrumen pengumpulan data menggunakan observasi partisipan dan wawancara. Analsis data dengan cara mereduksi data, penyajian data, dan penarikan kesimpulan. Hasil kajian menunjukkan ada delapan nilai di dalam aktivitas tersebut yang dikelompokkan menjadi nilai kekerabatan, serta memperoleh konstruksi pelaksanaan dalam melakukan aktivitas berkombur sebagai upaya modifikasi kecakapan interpersonal.
\end{abstract}

Kegiatan budaya di Indonesia sangatlah beraneka ragam. Salah satunya adalah aktivitas berkombur yang dimiliki budaya Melayu pesisir Kabupaten Batubara. Kegiatan ini sudah ada sejak zaman kerajaan Melayu Sumatera Utara. Aktivitas berkombur adalah sarana untuk bermasyarakat yang dapat diartikan sebagai berbicara, berdiskusi dengan tujuan sebagai sarana sosialisasi masyarakat Melayu Kabupaten Batubara. Selain itu, tujuan dari aktivitas ini merupakan obat stress dari semua aktivitas keseharian yang telah mereka lakukan. Barbagai individu maupun kelompok suatu suku dan bertemu dalam suatu wilayah, dengan membawa prilaku masing-masing akan menjadikan kebiasaan yang khas dari kelompok ataupun individu tersebut (Atmoko \& Faridati, 2015). Dari pendapat tersebut menunjukkan walupun masyarakat Batubara tersendiri dari beberapa suku dan adat istiadat serta kebiasaan masing-masing, mereka bersatu mengikuti adat istiadat daerah tersebut yaitu aktivitas berkombur dari dahulu sampai sekarang. 
Berdasarkan hasil observasi awal, memperlihatkan siswa-siswa sedang melakukan aktivitas berkombur ketika jam istirahat berbunyi. Salah satu diantara siswa tersebut sangat dominan dalam melakukan aktivitas berkombur tersebut. Mereka sangat terlihat gembira dan tertawa tidak ada habisnya. Peneliti mengonfirmasi kejadian tersebut dengan guru BK sekolah. Hasilnya guru BK menyebutkan itulah aktivitas berkombur budaya Melayu yang selalu dilakukan siswa-siswa di sela-sela pembelajaran mereka disekolah. Seperti ketika di awal pagi sebelum masuk bel berbunyi, ketika istirahat tiba, bahkan ketika bel pulang berbunyi. Mereka melakukan aktivitas berkombur tersebut setiap hari dan tempat pelaksanaannya mulai dari kantin sekolah, lapangan, dan dibawah pohon rindang sekolah.

Aktivitas ini juga dilakukan pada budaya lain, contohnya di Jawa dikenal dengan cangkrukan. Begitu pula pada daerah lain dengan nama yang berbeda. Akan tetapi, aktivitas berkombur tidak banyak diketahui masyarakat luas terkecuali daerah Kabupaten Batubara dan sekitarnya. Apalagi sampai dijadikan penelitian seperti kegiatan cangkrukan. Hingga sampai sekarang belum ada peneliti yang melakukan penelitian dengan mengkaji budaya berkombur ini secara mendalam. Aktivitas cangkrukan tersebut ialah wahana untuk berkomunikasi dan sosialisai yang tidak dapat dapat dipungkiri karena dengan kegiatan ini semua orang bisa membicarakan tema apapun. Penelitian terdahulu mengenai aktivitas cangkrukan ini sudah banyak dilakukan.

Peneliti mengambil contoh salah satu penelitian mengenai cangkrukan, dengan tujuan sebagai bahan refrensi dalam melakukan peneliti ini. Hasil dari salah satu penelitian menyebutkan cangkrukan biasanya hanya dilakukan di warung kopi (Santoso, 2017). Dalam kegiatan cangkrukan setiap warga dapat mengekspresikan diri dengan ikut berpartisipasi dalam setiap hubungan sosial satu dengan yang lain. Hasil penelitian ini sebagai penguat peneliti dalam melakukan penelitian pada aktivitas berkombur ini. Untuk kaitannya dengan dunia bimbingan dan konseling, aktivitas berkombur ini dapat digunakan guru BK sekolah sebagai salah satu teknik konseling dalam pelaksanaan konseling kelompok. Melalui pemberian teknik yang khas, serta unik dalam pelayanan bimbingan dan konseling baik di dalam kelas maupun di luar kelas. Akan membantu guru BK dalam hal mengembangkan diri siswanya (Mappiare-AT, 2012). Pendapat tersebut menunjukkan, dengan memberikan metode atau teknik yang khas pada suatu daerah seperti aktivitas berkombur akan dapat membantu siswa dalam pengembangan dirinya.

Aktivitas berkombur ini akan digunakan sebagai upaya modifikasi kecakapan interpersonal siswa. Kecakapan interpersonal adalah keseluruhan kemampuan yang dimiliki seseorang, yang akan digunakan untuk berinteraksi atau berhubungan secara efektif dengan orang lain (Johnson, 1993). Sehingga kapanpun individu tersebut berinteraksi dengan individu lain, apakah dengan teman, anggota keluarga, asosiasi bisnis, maupun penjaga toko, kecakapan interpersonal menjadi suatu keharusan yang dimiliki. Keterampilan interpersonal ini menentukan kemampuan seseorang tersebut dalam memulai, mengembangkan, memelihara kepedulian dan hubungan yang produktif dalam suatu proses interaksi. Dalam kecakapan interpersonal mempunyai pengaruh dalam mewujudkan kesejahteraan pribadi, sosial, dan perwujudan aktualisasi diri. Sehingga di dalam hubungan ada suatu proses interaksi didasarkan pada suatu siklus apa yang dirasakan orang lain dalam perbuatan, memutuskan bagaimana menanggapi, mengambil tindakan, serta kemudian merasakan respons individu lain.

Secara umum, kecakapan interpersonal meliputi empat area, yaitu (1) memahami dan percaya satu sama yang lainnya, (2) berkomunikasi secara akurat serta jelas antara satu dengan yang lainnya, (3) menerima dan mendukung satu dengan yang lainnya, dan (4) menyelasaikan konflik serta masalah secara konstruktif (Johnson, 1993). Dari masing-masing area tersebut dapat dijabarkan menjadi aspek sesuai dengan cakupan masalah dalam setiap area. Dari area ini akan dihubungkan dengan nilai yang terkandung dalam aktivitas berkombur.

Fokus dalam penelitian ini adalah bagaimana deskripsi nilai kekerabatan budaya melayu yang ada pada aktivitas berkombur, dan bagaimana prosedur aktivitas berkombur bermuatan nilai kekerabatan tersebut memodifikasi kecakapan siswa. Dalam penelitian ini ada beberapa keterbatasan yaitu penelitian ini hanya sampai pada tahap mendeskripsikan nilai-nilai yang terkandung dalam aktivitas berkombur saja. Setelah menemukan panduan pelaksanaan aktivitas berkombur tidak sampai tahap melakukan uji terhadap panduan tersebut. Penelitian ini diharapkan bermanfaat bagi peneliti sendiri, guru BK khsususnya budaya melayu Kabupaten Batubara dan peneliti lain yang akan meneliti hal yang sama.

\section{METODE}

Penelitian ini menggunakan pendekatan kualitiatif deskriptif sehingga laporan penelitian ini akan disusun dalam bentuk narasi bersifat deskriptif secara mendalam. Jenis penelitian pada penelitian ini menggunakan tipe Riset Dialog (RD). Menurut Silverman (dalam Mappiare-AT, 2013) mengatakan bahwa RD sangat beragam (heterogeneous) dan sulit didefinisikan secara spesifik, namun berupaya menganalisis aktivitas yang berwujud dalam perkataan dan perbincangan atau obrolan. Tujuan pokok RD adalah menemukan makna-makna sosial-budaya dan perilaku verbal dan nonverbal berbasis sosial-budaya sehingga membangun pendeskripsian dan penjelasan pola-pola saat sedang berdialog (Mappiare-AT, 2013). Riset dialog berupaya menganalisis aktivitas yang berwujud dalam perkataan dan perbincangan atau obrolan. Riset dialog bertujuan menemukan maknamakna sosial-budaya dan perilaku verbal dan nonverbal berbasis sosial-budaya sehingga membangun pendeskripsian dan penjelasan pola-pola saat sedang berdialog Interaksi dan komunikasi secara informal ataupun nonformal pada banyak orang merupakan hakikat pertama riset dialog. Komunikasi langsung berlaku pada individu yang diteliti. 
Untuk memperoleh deskripsi data yang lengkap tentang proses berkombur, peneliti memposisikan untuk melibatkan diri langsung dalam aktivitas berkombur siswa di sekolah maupun di lingkungan bermain, dan masyarakat di kawasan pesisir pantai Batubara. Pengumpul data utama memiliki peranan sepenuhnya dengan menemukan makna serta konstruk utuh dalam menggali nilai kekerabatan budaya Melayu. Kehadiran peneliti di dalam penelitian ini sebagai pengamat yang berpartisipasi dalam aktivitas ditempat penelitian. Sehingga instrumen pengumpulan data pada penelitian ini menggunakan observasi partisipan dan wawancara.

Penentuan lokasi penelitian harus benar-benar dipertimbangkan agar dapat diperoleh data yang dibutuhkan dan tercapainya tujuan penelitian itu sendiri. Penentuan lokasi penelitian yaitu salah satu SMA di Kabupaten Batubara dan pantai tempat berkumpulnya masyarakat pelaut. Subjek yang menjadi informan penelitian yaitu salah satu siswa SMA yang ahli dalam melakukan aktivitas berkombur, ditambah dengan salahs atu masyarakat pesisir pantai, Guru BK sekolah dan budaywan Melayu. Metode yang digunakan dalam penentuan subjek yaitu dengan teknik purposive sampling. Purposive sampling adalah suatu teknik untuk menentukan informan dengan beberapa pertimbangan tertentu yang bertujuan untuk data yang diperoleh nantinya akan lebih representatif (Sugiyono, 2010).

Analisis data pada penelitian ini yaitu mereduksi data, penyajian data, penarikan kesimpulan. Penelitian ini menggunakan sistem validitas agar mendapatkan data yang akurat atau keabsahan data. Penetapan keabsahan (trustworthiness) maka diperlukannya teknik pemeriksaan (Moleong, 2006). Pelaksanaan dalam teknik pemeriksaan ini didasarkan atas beberapa kriteria tertentu, yaitu derajat kepercayaan (credibility), keterlatihan (transferability), kebergantungan (dependability), dan kepastian (confirmability).

Tahapan dalam tipe riset dialog (RD) sebagai berikut. Pertama, mencari kelengkapan data, baik itu sumber data utama ataupun data tambahan. Kedua, mengumpulkan data utama dari proses aktivitas berkombur yang akan didapatkan dengan menggunakan observasi partisipasi. Peneliti menggunkan observasi partisipasi karena ingin terlibat langsung dalam kehidupan partisipan berkombur yaitu siswa, baik di lingkungan sekolah maupun di lingkungan rumah sehingga data yang didapatkan lebih akurat dan objektif. Peneliti juga mengamati dan terlibat dengan aktivitas berkombur masyarakat di lingkungan rumah siswa. Berkombur dilakukan secara alamiah, sehingga kapan, dimana, berapa alama, dan topik yang dibahas menyesuaikan keadaan ketika aktivitas tersebut berlangsung. Hal ini sudah mulai dilakukan peneliti sejak Desember 2018. Ketiga, mengumpulkan sumber data tambahan yakni menggunakan wawancara semi terstruktur yaitu peneliti secara bebas untuk mendapatkan informasi yang lebih mendalam tentang aktivitas berkombur secara mendalam dan dimulai bulan April-Juni 2019. Keempat, mengategorisasikan makna dari nilai-nilai berkombur yang telah didapat. Kelima, merancang prosedur aktivitas berkombur berdasarkan hasil instrumen data. Keenam, menghubungkan nilai-nilai yang didapat dengan teori dan hasil penelitian untuk memodifikasi kecakapan interpersonal siswa. Ketujuh, penulisan serta pelaporan hasil penelitian berupa karya ilmiah.

\section{HASIL}

Hasil penelitian ini yaitu nilai-nilai yang terkandung di dalam aktivitas berkombur, meliputi (1) keakraban, (2) keterbukaan, (3) kegembiraan, (4) guyon, (5) kebersamaan, (6) kepercayaan, (7) nilai dominasi, dan (8) kebiasaan. Nilai-nilai tersebut termasuk ke dalam nilai kekerabatan. Nilai kekerabatan adalah bagian dari budaya Melayu yang tidak terlepaskan dari kehidupan masyarakat Batubara. Sistem nilai kekerabatan ini merupakan rangkaian dari konsep-konsep abstrak dalam masyarakat. Masyarakat Melayu Batubara sudah menganggap semua masyarakat sebagai keluarga mereka karena merasa memiliki nenek moyang yang sama. Nilai-nilai ini akan dihubungkan dengan aspek pada kecakapan interpersonal. Aspek dalam pembahasan kecakapan interpersonal akan dihubungkan sesuai dengan jenis kecakapan dan nilai yang terkandung dalam kegiatan aktivitas berkombur. Secara deskriptif dijelaskan sesuai dengan aspek-aspek kecakapan interpersonal.

Pertama, memahami serta percaya antar satu dengan lainnya. Dari aspek ini adu dua jenis kecakapan yang harus dikuasai dan dua nilai yang berhubungan, yaitu membuka diri merupakan jenis kecakapan yang harus dikuasai siswa. Sesuai dengan nilai keterbukaan pada aktivitas berkombur. Ketika seseorang membuka dirinya otomatis akan bersifat terbuka dan menerima siapa saja untuk berhubungan dengannya. Selanjutnya, membangun kepercayaan antar individu. Dalam hal ini, nilai kebersamaan sangat sesuai untuk membangun kepercayaan dengan orang lain. Ketika seorang individu membangun kepercayaan dengan orang lain otomastis dia akan menanamkan nilai kebersamaan pada hubungan tersebut.

Kedua, berkomunikasi secara akurat dan jelas antara satu dengan yang lainnya. Jenis kecakapan yang pertama harus dikuasai adalah meningkatkan keterampilan berkomunikasi. Ketika individu berusaha meningkatkan keterampilan komunikasi, nilai dominasi harus tertanam pada dirinya. Semakin sering siswa tersebut berkomunikasi semakin terampil keahlian komunikasinya. Selanjutnya, mengekspresikan perasaan secara verbal maunpun nonverbal. Dalam aktivitas berkombur nilai guyon sangat kental yaitu ketika orang yang melakukan pekomburan mempraktikkan apa yang dikatakannya sehingga orang lain tertawa melihatnya.

Ketiga, menerima serta mendukung satu dengan yang lainnya. Aspek ini juga harus menguasi dua jenis kecakapan untuk mendukung tersebut. Meningkatkan kemampuan untuk mendengarkan sesuai dengan nilai kebiasaan. Semakin terbiasa siswa tersebut mendengarkan orang lain, akan menjadi timbal balik yaitu orang lain mau untuk mendengarkannya. Dalam hal meningkatkan kemampuan untuk menanggapi sesuai dengan nilai kegembiraan. Ketika siswa merasa gembira dengan aktivitas tersebut semakin tinggi kemauannya untuk menanggapi ataupun aktif dalam kelompok tersebut. 
Keempat, menyelesaikan konflik serta masalah secara konsruktif. Diawali dengan keterampilan menyelesaikan konflik yang ada pada dirinya menyebabkan siswa tersbut mengamali kepercayaan diri. Nilai kepercayaan ini sejalan dengan jenis kecakapan yang harus dikuasai. Untuk menyelesaikan masalah dengan orang lain secara konstruktif harus dimunculkan nilai keakraban. Sehingga ketika nilai keakraban itu ada, antar siswa tersebut merasa masalah yang mereka hadapi itu terselesaikan. Setelah membahas dari kecakapan interpersonal dengan menghubungkan nilai kekerabatan budaya berkombur. Selanjutnya uraian dari temuan penelitian tersebut akan dijadikan acuan dalam prosedur aktivitas berkombur sebagai strategi teknik konseling untuk memodifikasi kecakapan interpersonal siswa, yaitu sebagai berikut.

Pertama, pemahaman mengenai aktivitas berkombur. Aktivitas berkombur asli khas Melayu yang harus dilestarikan dikarenakan kegiatannya mengadung hal yang sangat positif. Berkombur selalu ditemukan dan sudah menjadi kebiasaan yang dilakukan. Tujuan utama dari kegiatan ini dapat menghilangkan rasa letih aktivitas seharian setiap orang yang melakukan aktivitas berkombur tersebut.

Kedua, peserta kegiatan berkombur. Peserta yang melakukan kegiatan berkombur atau aktor utamanya biasanya memiliki pengalaman dan dipercaya untuk didengar informasi yang diucapkannya. Jadi, posisi tersebut bisa dilakukan oleh para remaja, dewasa, orangtua dan dari strata sosial manapun.

Ketiga, topik yang dibahas. Topik yang dibahas dalam kegiatan berkombur ini sesuai dengan pekerjaan, umur, dan kegemaran orang-orang didalam kelompok tersebut. Sedikit berbeda dengan topik yang dibahas orang tua dari remaja yaitu tentang pendidikan, kebijakan pemerintah dan seputar politik.

Keempat, manfat kegiatan. Secara keseluruhan, manfaat dari aktivitas berkombur ini sangat positif, dan sangat banyak. Mulai dari pusat bertukar informasi, mempererat tali silaturahmi, menghilangkan rasa letih aktivitas seharian, sarana hiburan, dan sampai dengan penyelesaian sampai pemberian solusi ketika ada permasalahan dalam kelompok tersebut.

Kelima, syarat bergabung dengan aktivitas berkombur. Syarat utama bergabung menjadi anggota aktivitas berkombur tidak memandang strata sosial, cukup umur bila yang melaksanakan orangtua. Sehingga orang tersebut mengerti apa yang dibahas dalam kegiatan berkombur tersebut.

Keenam, tahapan-tahapan. Secara lengkap tahapan-tahapan melakukan aktivitas berkombur, meliputi (1) mengumpulkan anggota untuk melakukan aktivitas tersebut, biasanya kalau selalu dilakukan berkumpul dengan sendirinya; (2) menunggu kedatangan ahli pekombur, bila sudah ada langsung dimulai; (3) membahas topik ringan untuk pembukaan, yaitu aktivitas keseharian si pekombur; (4) menanyakan kepada teman-teman dalam anggota untuk pembahasan apa yang ingin dibahas, sesuai dengan kesepakatan; (5) melakukan aktivitas berkombur dengan membahas tema sesuai kesepakatan dengan selalu menyelipkan guyon-guyon sebagai bumbu cerita. Sehingga orang yang mendengar tidak jenuh dan informasi yang dibahas sampai dengan orang yang mendengar; (6) memperagakan apa yang terjadi, sehingga bahasa tubuh sejalan dengan ucapan; (7) setelah puas mebahas pembahasan utama, kawan-kawan yang lain menanggapi atau menambahkan cerita; (8) terjadi perdebatan yang menarik dan menimbulkan lelucuan yang baru; (9) ketika pembahasan selesai, bila ada topik menarik dari anggota lain maka akan menjadi pembahasan penutup; (10) biasanya ditutup dengan pantun melayu.

Ketujuh, waktu dan tempat. Waktu pelaksanaan berkombur ini dilakukan ketika tidak ada aktivitas keseharian, atau waktu istirahat maupun ketika pulang dari aktivitas pekerjaan seharian. Tempat pelaksanaan kondisional dalam arti dimana mereka berkumpul, baik itu di warung, lingkungan sekolah, maupun di pantai.

Kedelapan, berapa kali pertemuan. Untuk mahir melakukan aktivias ini harus menjadi pendengar yang baik sehari-hari. Sehingga ketika sudah bisa melakukan aktivitas berkombur, orang tersebut tidak bisa terlepas dari kegiatan ini dan akhirnya bisa melakukan aktivitas ini disela-sela kesibukan aktivitasnya.

Kesembilan, azas kerahasian. Kegiatan ini ternyata dalam hal kerahasian sangat terjaga, sehingga orang yang tidak ada saat pelaksanaan kegiatan tersebut tidak mengetahui informasi yang dibahas.

Kesepuluh, larangan dalam kegiatan. Berkombur menjadi pembeda dari bergosip yaitu dari sisi larangan. Larangan yang tidak boleh dilakukan yaitu membahas permasalahan orang lain, menjelekkan suku, ras, serta agama lain. Sehingga seperti manfaat di awal tadi bahwa tidak membeda-bedakan strata sosial antara sesama anggota tersebut.

Kesebelas, menjadikan aktivitas berkombur sebagai teknik konseling. Menjadikan aktivitas berkombur sebagai salah satu teknik konseling dalam pelayanan bimbingan dan konseling di sekolah adalah salah satu solusi yang baik. Tidak menghilangkan unsur budaya di daerah tersebut dan menjadikan sebagai salah satu teknik konseling. 
Tabel 1. Kerangka Temuan Penelitian

\begin{tabular}{|c|c|c|c|c|c|c|}
\hline \multirow{8}{*}{$\begin{array}{c}\text { Tema Bahasan: } \\
\text { Kecakapan } \\
\text { Interpersonal }\end{array}$} & \multirow{8}{*}{$\frac{n}{4}$} & \multirow{2}{*}{$\begin{array}{l}\text { Memahami dan percaya antar satu } \\
\text { dengan yang lainnya }\end{array}$} & \multirow{8}{*}{ 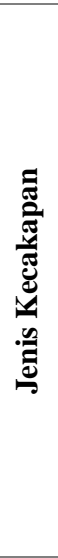 } & Membuka diri & \multirow{8}{*}{ 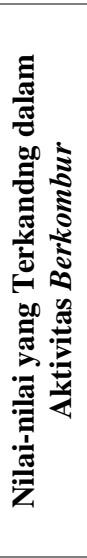 } & Keterbukaan \\
\hline & & & & $\begin{array}{l}\text { Membangun kepercayaan antar } \\
\text { individu }\end{array}$ & & Kebersamaan \\
\hline & & \multirow[t]{2}{*}{$\begin{array}{l}\text { Berkomunikasi secara akurat serta jelas } \\
\text { antar satu dengan yang lainnya }\end{array}$} & & $\begin{array}{l}\text { Meningkatkan keterampilan } \\
\text { berkomunikasi }\end{array}$ & & Dominasi \\
\hline & & & & $\begin{array}{l}\text { Mengekspresikan perasaan secara } \\
\text { verbal maupun non verbal }\end{array}$ & & Guyon \\
\hline & & \multirow[t]{2}{*}{$\begin{array}{l}\text { Menerima serta mendukung satu } \\
\text { dengan yang lainnya }\end{array}$} & & $\begin{array}{l}\text { Meningkatkan kemampuan untuk } \\
\text { mendengarkan }\end{array}$ & & Kebiasaan \\
\hline & & & & $\begin{array}{l}\text { Meningkatkan kemampuan untuk } \\
\text { menanggapi }\end{array}$ & & Kegembiraan \\
\hline & & \multirow[t]{2}{*}{$\begin{array}{l}\text { Menyelesaikan konflik serta masalah } \\
\text { secara konstruktif }\end{array}$} & & $\begin{array}{l}\text { Menyelesaikan konflik yang ada } \\
\text { pada dirinya }\end{array}$ & & Kepercayaan \\
\hline & & & & $\begin{array}{l}\text { Menyelesaikan masalah } \\
\text { antarpribadi }\end{array}$ & & Keakraban \\
\hline
\end{tabular}

Tabel 1 menjelaskan mengenai kerangka temuan pada penelitian kali ini. Hasil dari nilai-nilai yang ditemukan dikelompokkan dengan aspek serta jenis kecakapan yang harus dimiliki.

\section{PEMBAHASAN}

Nilai-nilai dalam aktivitas berkombur akan diperkuat dengan jurnal penelitian. Berikut hasil dari pembahasan nilai-nilai dalam aktivitas berkombur dan diperkuat dengan jurnal penelitian. Nilai pertama yaitu nilai keakraban. Dalam aktivitas berkombur siswa mempererat hubungan persahabatan diatara mereka."Keakraban yang lebih tinggi akan mengarah pada presepsi norma yang lebih kritis, eksploratif, dan komunikasi yang lebih positif” (Janssen, Erkens, Kirschner, \& Kanselaar, 2009). Dengan kelompok yang akrab, siswa hanya perlu waktu lebih sedikit dalam mengatur kegiatan yang berkaitan dengan tugas mereka. Sehingga nilai keakraban ini sangatlah penting pada siswa dalam kelompok.

Setelah nilai keakraban, peneliti menemukan nilai keterbukaan dari aktivitas berkombur siswa. Keterbukaan secara harfiah adalah jernih, tembus, nyata dan jelas. Keterbukaan merupakan perwujudan dari sikap jujur dan rendah hati menerima pendapat dan kritik maupun saran dari orang lain. Hasil dari suatu artikel penelitian menunjukkan efek secara khusus siswa yang lebih memiliki sikap terbuka, fleksibel dan empatik akan menunjukkan keterbukaan terhadap keanekaragaman dan penyesuaian yang semakin baik (Yakunina, Weigold, Weigold, Hercegovac, \& Elsayed, 2012). Sehingga kesimpulan dari hasil penelitian dan lapangan bahwa keterbukaan pada diri siswa memiliki peranan penting dalam menyesuaikan diri dengan lingkungan. Selanjutnya, nilai yang terdapat pada aktivitas berkombur yaitu kegembiraan. Kegembiraan atau kebahagian hidup adalah suatu konsep yang mengacu pada emosi positif yang dirasakan dan aktivitas positif yang disukai suatu individu (Seligmen, 2005). Bagian ini ditandai degan lebih banyak energi positif yang dirasakan individu dibandingkan energi negatif. Dengan kegembiraan yang ada dalam diri siswa diharapkan akan lebih mengedepankan energi-energi positif sehingga memunculkan kegiatan yang positif juga.

Nilai keempat yang ditemukan adalah guyon atau humor ataupun bercanda. Humor secara sederhana didefenisikan sesuatu yang lucu. Humor merupakan respon terhadap presepsi ketidaksesuaian di dalam situasi bercanda yang bisa disertai senyum maupun tawa atau bisa saja tidak (McGHEE, 1980). Teori ini diperkuat dengan sebuah penelitian yang menunjukkan humor, peningkatan diri, dan kesejahteraan memiliki hubungan yang kuat (Dyck \& Holtzman, 2013). Sehingga semakin tinggi selera humor sesorang akan meningkatkan hubungan positif dengan orang lain dan juga akan meningkatkan diri dan kesejahteraannya.

Nilai kelima ialah nilai kebersamaan yang ditemukan dalam aktivitas berkombur. Kebersamaan memiliki makna ikatan yang terbentuk dikarenkan rasa persaudaraan ataupun kekeluargaan melebihi dari sekedar bekerjasama atau hubungan profesional biasa. Sehingga rasa kebersamaan masyarakat siswa di Kabupaten Batubara sangat terjaga. Sejalan dengan fakta ini, hasil dari salah satu artikel penelitian menunjukkan setiap individu yang terlibat dalam kegiatan bersama orang lain dapat menciptakan harapan yang lebih baik di masa depan (Nyman, Josephsson, \& Isaksson, 2012). Sehingga partisispasi individu dalam kegiatan sehari-hari dalam proses sosial secara tidak langsung mengubah prespektif orang di sekitarnya postif terhadap dirinya.

Nilai keenam dalam aktivitas berkombur adalah kepercayaan. Kepercayaan dalam aktivitas tersebut menunjukkan setiap orang yang melakukan berkombur dengan rasa percaya diri tanpa ada rasa malu dalam menceritakan kehidupannya. Sehingga nilai kepercayaan diri ini bisa menular ke siswa-siswa yang lain. Hasil dari suatu penelitian menujukkan konseling kelompok efektif dalam meningkatkan kepercayaan diri siswa (Imro'atun, 2017). Strategi kelompok akan membantu siswa lain dalam modifikasi kecakapan interpersonalnya.

Nilai ketujuh ialah dominasi yang terkandung dalam aktivitas berkombur yaitu untuk orang yang melakukannya. Yaitu orang yang melakukan aktivitas tersebut mulai dari awal sampai akhir kegiatan paling mnguasai forum. Tetapi individu tersebut yang paling disukai dan ditunggu aksi perkomburannya. Menurut hasil penelitian menyimpulkan budaya dominan dalam lingkungan tertentu dengan aturan dan norma harus diikuti oleh orang luar (Suparlan, 2006). Oleh karena itu, bila dihubungkan 
dengan temuan penelitian dari aktivitas berkombur bahwa memang benar ketika orang yang mendominasi pada aktivitas tersebut, orang lain yang hanya sebagai pendengar harus mengikuti dan mendengarkannya sehingga terjadi satu pemikiran yang sejalan diantara kelompok terebut.

Nilai terakhir adalah kebiasaan. Hasil dari suatu penelitian menunjukkan pada kebiasaan pekerjaan yang dilakukan pria dan diujicobakan kepada wanita (Devine et al., 2017). Hasilnya ketika kebiasaan itu dilakukan secara terus-menerus wanita tersebut sama kemampuannya dengan para pria dengan pekerjaaan yang sama. Kesimpulannya bahwa setiap pekerjaan ataupun kegiatan yang terbiasa dilakukan dan diulang-ulang akan menguasi kegiatan atau pekerjaan tersebut. Begitu juga dengan nilai kebiasaan pada aktivitas berkombur ini karena sering melihat dan mempraktikkan berulang-ulang, akan membuat individu mampu melakukan kegiatan tersebut dengan baik.

Nilai-nilai dalam aktivitas berkombur ini menurut pembahasan teori, jurnal penelitian, ditambah data dari narsumber dan interpretasi peneliti bahwa nilai-nilai yang dikelompokkan menjadi nilai kekerabatan ini akan dijadikan upaya dalam modifikasi kecakapan interpersonal siswa. Masing-masing area pada kecakapan interpersonal dapat dijabarkan menjadi aspek sesuai dengan cakupan masalah dalam setiap area. Berikut dijelaskan secara jelas nilai-nilai kekerabatan dalam aktivitas berkombur untuk memodifikasi kecakapan interpersonal siswa. Berikut rinciannya secara deskriptif peneliti jabarakan. (1) Memahami serta percaya antara satu dengan lainnya. Dari aspek ini, ada dua jenis kecakapan yang harus dikuasai dan dua nilai yang berhubungan, yaitu keterampilan membuka diri dan membangun kepercayaan antara individu. Membuka diri adalah mengemukakan bagaimana reaksi terhadap suatu situasi yang sedang dialami disaat ini dan memberikan informasi yang sesuai atau relevan tentang masa lalu sebagai usaha dengan tujuan memahami mengapa reaksi tersebut muncul pada saat tertentu. Hasil dari suatu penelitian menunjukkan bahwa hubungan positif sangat signifikan antara dukungan sosial dan penerimaan diri atau membuka diri pada usia lanjut (Marni \& Yuniawati, 2015). Dengan kata lain, keterampilan ini akan menambah hubungan positif hingga jangka waktu yang panjang. Sejalan dengan nilai keterbukaan pada aktivitas berkombur. Semakin terbuka orang yang melakukan aktivitas tersebut, semakin poositif hubungan diantara mereka membangun kepercayaan antar individu ini. Hasil dari salah jurnal penelitian menunjukkan dari ketiga percobaan yang dilakukannya, salah satunya menunjukkan adanya pengaruh secara signifikan kepribadian dan kualitas persahabatan dengan membangun kepercayaan (Rahmat, 2014). Sehingga dalam membangun kpercayaan tersebut berpengaruh terhadap kepribadian dan persahabatan dari setiap individu. Dalam aktivitas berkombur hal ini bisa sejalan dengan nilai kebersamaan. Nilai kebersamaan ini akan membuat kualitas persahabatan dan kepribadian sesama individu memiliki rasa kepercayaan yang tinggi.

(2) Area kedua yaitu berkomunikasi secara akurat serta jelas antara satu deengan yang lain. Jenis kecakapan yang harus dikuasai adalah meningkatkan keterampilan berkomunikasi dan mengekspresikan perasaan secara verbal maupun non verbal. Ketika individu berusaha meningkatkan keterampilan komunikasi, nilai dominasi harus tertanam pada dirinya. Nilai dominasi ini ada pada aktivitas berkombur. Semakin sering siswa tersebut berkomunikasi semakin terampil keahlian komunikasinya. Menurut dari hasil suatu penelitian intervensi pelatihan teknik role playing dapat meningkatkan komunikasi interpersonal seseorang (Dharmayanti, 2013). Dengan pengertian bahwa pelatihan yang sering dilakukan seperti dominasi pada aktivitas berkombur dapat membuat individu meningkat keterampilan berkomnukasinya. Dalam aktivitas berkombur, nilai guyon sangat kental yaitu ketika orang yang melakukan pekomburan memperagakan apa yang dikatakannya. Sehingga orang lain tertawa melihatnya. Berhubungan dengan keterampilan ini yaitu mengekspresikan perasaan verbal maupun nonverbal. Diperkuat dengan hasil penelitian yang menyatakan bahwa selain bahasa verbal, bahasa nonverbal sangat memengaruhi perilaku komunikasi siswa dalam pembelajaran (Sitompul, 2012). Kesimpulannya bahwa untuk berkomunikasi secara akurat dan jelas antar satu dengan yang lain baik verbal dan nonverbal harus seiring berjalan.

(3) Menerima serta mendukung satu dengan yang lainnya. Aspek yang ketiga yaitu menerima serta mendukung satu dengan yang lain. Untuk mendukung aspek ini, ada dua jenis kecakapan yang harus dikuasi yaitu meningkatkan kemampuan untuk mendengarkan dan meningkatkan kemampuan untuk menanggapi. Meningkatkan kemampuan untuk mendengarkan sejalan dengan nilai kebiasaan pada aktivitas berkombur. Semakin terbiasa individu tersebut mendengarkan orang lain, akan menjadi timbali balik yaitu orang lain mau untuk mendengarkannya. Dari kebiasaan mendengarkan akan semakin cepat memahami dari apa yang didengarkan tersebut. Sejalan dengan kemampuan yang pertama yaitu kemampuan mendengarkan dengan kemampuan yang kan dibahas kali ini yaitu keampuan menanggapi. Ketika individu tersebut sudah memahami dari keterbiasaan dalam medengarkan, Individu tersebut akan meningkatkan keterampilan untuk menanggapi. Hal ini seperti salah satu nilai terkandung dalam aktivitas berkombur yaitu nilai kegembiraan. Ketika iya merasa gembira, keyakinannya semakin bertambah untuk menanggapi sesuatu dalam pembicaraan ataupun forum diskusi.

(4) Menyelesaikan konflik serta masalah secara konstruktif. Untuk aspek yang terakhir dalam pembahasan kecakapan interpersonal ini ialah menyelesaikan konflik serta masalah secara konsruktif. Jenis kecakapan yang harus dikuasi individu dalam hal ini ada dua yaitu menyelesaikan konflik pada dirinya dan dengan orang lain. Diawali dengan keterampilan menyesaikan konflik yang ada pada dirinya menyebabkan individu tersebut mengamali kepercayaan diri. Sehingga nilai kepercayaan ini sangat sejalan dengan jenis kecakapan yang harus dikuasinya. Ketika individu tersebut memiliki nilai kepercayaan yang tertanam pada dirinya, ini akan menjadi bekalnya untuk menyelesakam konflik pada dirinya dan orang lain. Nilai kepercayaan ini tertanam pada aktivitas berkombur budaya Melayu Kabupaten Batubara. Untuk pembahasan yang terakhir adalah menyelesaikan masalah antar pribadi. Setelah siswa tersebut menyelesaikan konflik pada dirinya, lalu selanjutnya menyelesaikan masalah antarpribadi. Untuk menyelesaikan masalah dengan orang lain secara konstruktif harus dimunculkan nilai keakraban pada mereka. Sehingga ketika 
nilai keakraban itu ada, antar siswa tersebut merasa masalah yang mereka hadapi itu terselesaikan. Hasil dari salah satu penelitian menunjukkan kemampuan untuk menyelesaikan masalah penting bagi tahapan perkembangan manusia (Kusuma, 2009). Ini dapat mengarahkan pada hubungan yang produktif serta harmonis sehingga nilai keakraban ini dapat dimunculkan untuk menyelesaikan permasalahan antar pribadi secara konstruktif.

\section{SIMPULAN}

Nilai-nilai yang terkandung dalam aktivitas ini, meliputi (1) keakraban, (2) keterbukaan, (3) kegembiraan, (4) guyon, (5) kebersamaan, (6) kepercayaan, (7) nilai dominasi, dan (8) kebiasaan. Nilai-nilai ini dikelompokkan menjadi nilai kekerabatan. Konstruksi Berkombur bermuatan nilai kekerabatan yang telah dijabarkan pada pembahasan sebelumnya oleh peneliti, dengan tujuan akan digunakan sebagai modifikasi kecakapan interpersonal siswa. Setelah mengetahui prosedur konstruksi aktivitas berkombur tersebut menjadi teknik konseling. Baru akan digunakan sebagai memodifikasi kecakapan interpersonal siswa. Kecakapan interpersonal meliputi emapat aspek area, yaitu (1) memahami dan percaya satu sama yang lainnya, (2) berkomunikasi secara akurat serta jelas antara satu dengan yang lainnya, (3) menerima dan mendukung satu dengan yang lainnya, (4) menyelesaikan konflik serta masalah secara konstruktif. Kesimpulan pada penelitian ini menghasilkan prosedur aktivitas berkombur sebagai teknik konseling untuk memodifikasi kecakapan interpersonal.

Prosedur aktivitas berkombur, meliputi (1) pemahaman mengenai aktivitas berkombur, (2) peserta kegiatan, (3) topik, (4) manfaat, (5) syarat bergabung, (6) tahapan, (7) waktu dan tempat, (8) berapa kali pertemuan, (9) azas kerahasian, (10) larangan dalam kegiatan, dan (11) menjadikan sebagai teknik konseling.

Kepada guru BK sekolah khususnya budaya Melayu Kabupaten Batubara, hasil penelitian ini diharapkan dapat digunakan sebagai solusi memodifikasi kecakapan interpersonal siswa. Kepada peneliti lain diharapkan dapat menggunakan jenis penelitian R \& B untuk melakukan tahap uji coba terhadap panduan pelaksanaan yang dihasilkan ataupun menggunakan eksperiment dengan melihat keefektifan antara panduan aktivitas berkombur dengan kecakapan interpersonal.

\section{DAFTAR RUJUKAN}

Atmoko, A., \& Faridati, E. (2015). Bimbingan Konseling untuk Multikultural di Sekolah. Malang: Malang Mas.

Devine, P. G., Forscher, P. S., Cox, W. T. L., Kaatz, A., Sheridan, J., \& Carnes, M. (2017). A Gender Bias Habit-Breaking Intervention LED to Increased Hiring of Female Faculty in STEMM Departments. Journal of Experimental Social Psychology, 73(February), 211-215. https://doi.org/10.1016/j.jesp.2017.07.002

Dharmayanti, P. A. (2013). Teknik Role Playing Dalam Meningkatkan Keterampilan Komunikasi Interpersonal Siswa SMK. Jurnal Pendidikan dan Pengajaran, 46(3), 256-265.

Dyck, K. T. H., \& Holtzman, S. (2013). Understanding Humor Styles and Well-Being: The Importance of Social Relationships and Gender. Personality and Individual Differences, 55(1), 53-58. https://doi.org/10.1016/j.paid.2013.01.023

Imro'atun, S. (2017). Keefektifan Layanan Konseling Kelompok untuk Meningkatkan Kepercayaan Diri Siswa Sekolah Menengah Pertama. Jurnal Kajian Bimbingan dan Konseling, 2(2), 50-57. https://doi.org/10.17977/um001v2i22017p050

Janssen, J., Erkens, G., Kirschner, P. A., \& Kanselaar, G. (2009). Influence of Group Member Familiarity on Online Collaborative Learning. Computers in Human Behavior, 25(1), 161-170. https://doi.org/10.1016/j.chb.2008.08.010

Johnson, D. W. (1993). Reaching Out: Interpersonal Effectiveness and Self Actualization 5th ed. Needham Haights: A Devision of Simon \& Schuster, Ins.

Kusuma, R. S. (2009). Komunikasi Antar Pribadi sebagai Solusi Konflik pada Hubungan Remaja dan Orangtua di SMK Batik 2 Surakarta. Warta LPM, 20(1), 49-54.

Mappiare-AT, A. (2012). Bimbingan Konseling pada Pendidikan Dasar Dalam Kontemporer. Bimbingan dan Konseling pada Pendidikan Dasar, 21(2), 178-187.

Mappiare-AT, A. (2013). Tipe-tipe Metode Riset Kualitatif untuk Eksplanasi Sosial Budaya dan Bimbingan Konseling. Malang: Elang Mas.

Marni, A., \& Yuniawati, R. (2015). Hubungan antara Dukungan Sosial dengan Penerimaan diri pada Lansia. Empathy, 3(1), 17.

McGHEE, P. E. (1980). Developmental of The Creative Aspects of Humour. Chishester: John Wiley \& Sons Ltd.

Moleong, L. J. (2006). Metodologi Penelitian Kualitatif. Bandung: PT. Remaja Rosda Karya.

Nyman, A., Josephsson, S., \& Isaksson, G. (2012). Being Part of an Enacted Togetherness: Narratives of Elderly People with Depression. Journal of Aging Studies, 26(4), 410-418. https://doi.org/10.1016/j.jaging.2012.05.003

Rahmat, W. (2014). Pengaruh Tipe Kepribadian dan Kualitas Persahabatan dengan Kepercayaan Pada Remaja Akhir. EJournal Psikologi, 2(2), 206-216.

Santoso, L. S. (2017). Etnografi Warung Kopi: Politik Identitas Cangkrukan di Kota Surabaya dan Sidoarjo. Mozaik Humaniora, 17(1), 113-125. https://doi.org/10.20473/MH.V17I1.6594

Seligmen, M. E. P. (2005). Menciptakan Kebahagian dengan Psikologi Positif (Authentic Happiness). Bandung: PT. Mizan Pustaka. 
1434 Jurnal Pendidikan, Vol. 4, No. 10, Bln Oktober, Thn 2019, Hal 1427-1434

Sitompul, N. C. (2012). Perilaku Komunikasi Nonverbal Guru Dalam Kelas Pembelajaran: Maknanya bagi Siswa SMA. Jurnal Pendidikan dan Pembelajaran, 19(44), 38-49.

Sugiyono. (2010). Metode Penelitian Kuantitatif, Kualitatif, dan R\&B. Bandung: Alfabeta.

Suparlan, P. (2006). Kemajemukan, Hipotesis Kebudayaan Dominan. Antropologi Indonesia, 30(3), $229-236$.

Yakunina, E. S., Weigold, I. K., Weigold, A., Hercegovac, S., \& Elsayed, N. (2012). The Multicultural Personality: Does it Predict International Students' Openness to Diversity and Adjustment? International Journal of Intercultural Relations, 36(4), 533-540. https://doi.org/10.1016/j.ijintrel.2011.12.008 